\title{
LEAF AREA INDEX OF GROUND COVERS IN A SUBTROPICAL WATERSHED
}

\author{
Alexandre Cândido Xavier; Carlos Alberto Vettorazzi* \\ USP/ESALQ - Depto. de Engenharia Rural, C.P. 9 - 13418-900 - Piracicaba, SP-Brasil. \\ *Corresponding author <cavettor@esalq.usp.br>
}

\begin{abstract}
Leaf Area Index (LAI), an important structural variable descriptive of vegetation, is directly related to evapotranspiration and productivity. The objective of this work was to measure and analyze monthly LAI of different ground covers in a subtropical watershed. A field campaign to collect monthly LAI data was carried out during the year 2001, with a LAI-2000 (plant canopy analyzer) device, in sugarcane, pasture, corn, eucalypt, and riparian forest patches. Riparian forest presented a maximum LAI of 4.90; LAI values decreased as precipitation decreased, as it is a characteristic of this type of semideciduous vegetation. LAI for sugar cane presented the greatest variability throughout the year, related to plant characteristics and crop management in the study area. Results represent an initial step for the understanding of LAI dynamics in the study area and areas under similar conditions.

Key words: LAI-2000, plant canopy, biophysical variable

\section{ÍNDICE DE ÁREA FOLIAR DE COBERTURAS DO SOLO EM UMA MICROBACIA HIDROGRÁFICA SUBTROPICAL}

\begin{abstract}
RESUMO: O Índice de Área Foliar (IAF) é uma importante variável estrutural descritora da vegetação, diretamente relacionada com a evapotranspiração e a produtividade. O objetivo deste trabalho foi estruturar e analisar um banco de dados de valores mensais de IAF de diferentes coberturas do solo em uma microbacia hidrográfica subtropical. Uma campanha de campo de coleta de dados mensais de IAF, com o auxílio do equipamento LAI-2000 (analisador de dossel de plantas), foi realizada durante o ano de 2001, em áreas de cana-de-açúcar, pastagem, milho, eucalipto e floresta ripária. O valor máximo do IAF foi de 4,90, para floresta ripária; este valor apresentou uma queda com a diminuição da precipitação, característica deste tipo de vegetação semidecidual. O IAF da cana-de-açúcar apresentou a maior variabilidade durante o período de coleta, devido às características próprias da cultura e seu manejo na área em estudo. Os resultados apresentados representam um passo inicial para o entendimento da dinâmica do IAF na área em estudo e áreas similares.

Palavras-chave: LAI-2000, dossel, variável biofísica
\end{abstract}

\section{INTRODUCTION}

Leaf Area Index (LAI), the ratio of leaf area per soil surface area (Watson, 1947), is an important structural variable of vegetation, and associated by modelling, with variations in primary net yield (Matsushita \& Tamura, 2002) and evapotranspiration for a given area (Sellers et al., 1997), as well as with climatic global changes (Betts et al., 1997). LAI models are directly related to several physical processes of the vegetation; for example: the fraction of photosynthetically active radiation that is absorbed by the canopy (Wiegand \& Richardson, 1990); the canopy's ability to intercept rain (van Dijk \& Bruijnzeel, 2001); the canopy's resistance and conductance (Saigusa et al., 1998); etc.

Remote Sensing (RS) data is the only possible way to estimate this variable and calculating evapotranspiration on a regional basis. One convenient way of estimating LAI by RS is using relational functions between
Vegetation Indices (VIs) and LAI (Myneni et al., 1995). However, VIs are sensitive to the combined effect of the canopy's structure and the sun-sensor geometry (Goetz, 1997; Deering et al., 1999), making it difficult to estimate LAI without an adequate calibration of this variable with LAI data acquired in the study area at the same time RS data were collected.

The study of LAI has been performed in a very intense and systematic way for different types of ground covers (Turner et al., 1999). However, surveys for this variable are rare in Brazil and are generally carried out for only a few ground cover types; studies by Machado et al. (1982) (sugarcane) and Roberts et al. (1996) (forest and pasture areas) can be cited as examples. The objective of this work was to lay the foundation for a database and to analyze monthly LAI data, during a 12month period, for different types of plant covers riparian forest, eucalyptus, sugarcane, pasture and maize - in a subtropical watershed, aiming to understand its dynamics. 


\section{MATERIAL AND METHODS}

\section{Study area}

The study area was the Ribeirão dos Marins watershed, an area of approximately 5,973 ha located between coordinates $22^{\circ} 41^{\prime} \mathrm{S}$ and $22^{\circ} 51^{\prime} \mathrm{S}$, and $47^{\circ} 40^{\prime} \mathrm{W}$ and $47^{\circ} 45^{\prime} \mathrm{W}$, in Piracicaba, SP, Brazil. The watershed is part of the State of São Paulo's Hydrological Network, and is operated by the Departamento de Águas e Energia Elétrica e Centro Tecnológico de Hidráulica, Universidade de São Paulo. Several hydrological instruments, such as pluviographs and a limnimetric station, are installed in the area. Region's climate is subtropical humid (Cwa), according to Koeppen's classification, with rainy summer and dry winter; mean annual precipitation is $1278.0 \mathrm{~mm}$ (Sentelhas et al., 1998). The soils in the region are represented by Typic Paleudults, Rhodic Eutrudox, Rhodic Hapludox, Xanthic, Lithic Udorthents and Kandiudalfic Eutrudox (Oliveira, 1999). The topography of the area varies between rolling and strongly rolling hills (Teramoto, 1995).

\section{LAI Data Collection}

Between the $15^{\text {th }}$ and the $20^{\text {th }}$ day of each month, 41 areas were visited and LAI was measured with a plant canopy analyzer, model LAI-2000 (LI-COR, 1992), according to the presence of vegetation in the area. To calculate LAI, the LAI-2000 device utilizes the canopy's gap fraction, which allows a view of the sky in some directions below the canopy (Welles, 1990). The ratio between readings obtained with the LAI-2000 below the canopy and those obtained outside the canopy is utilized to obtain an estimate of the gap fraction in five angles: LAI is them calculated based on those readings, as follows:

$$
\mathrm{LAI}=2 \sum_{i=1}^{5} \frac{-\ln \left(T_{i}\right)}{S_{i}} W_{i}
$$

where: $T_{i}$ represents the 5 gap fractions; $W_{i}$ represents $\sin \theta d \theta$ for the five view angles of the LAI-2000 sensor; $S_{i}=1 / \cos \theta$; and $\theta$ is the zenith angle.

Areas for LAI evaluation represented the existing variety of land uses and ground covers in the watershed; showed homogeneous traits, such as plant vigor, height and distribution; allowed the selection of a greater number of sugarcane samples, since this crop occupies the largest area of occurrence and presents great LAI variability in a given period, related to variations in planting season. To avoid underestimation, LAI measurements were performed in cloudy days, and when that was not possible, measurements were taken before 9:00 a.m. and after 4:00 p.m., when solar elevation angle was smaller, and the sensor was kept constantly in the shade. The number of replicates per type of land use was calculated according to the LI-COR (1992) methodology. Six replicates were performed with the sensor within the canopy, and the number of replicates necessary to estimate the true mean was determined by the ratio between the corresponding standard deviation and replicates mean, at the $95 \%$ confidence level.

The numbers of replicates determined for sugarcane, maize and pasture areas were 16 for replicates made within and 2 made above the canopy, while for native forest and eucalyptus plantations, those numbers were 10 for replicates below, and 1 for replicates above the canopy. With respect to the distribution of LAI measurements under the canopy, measurements were made within the canopy in sugarcane and maize by varying the position among planting rows. The measurement height in those crops varied according to the presence of senescent leaves, and an attempt was made to avoid these, by always raising the sensor above them. In eucalyptus plantations, the row spacing between replicates was preferentially $5 \mathrm{~m}$ at $0.5 \mathrm{~m}$ above the ground.

\section{RESULTS AND DISCUSSION}

During the field campaign, the mean temperature was $22.5^{\circ} \mathrm{C}$ (annual mean of $21.4^{\circ} \mathrm{C}$ ) with a mean monthly maximum of $26.0^{\circ} \mathrm{C}$ and mean monthly minimum of $18.5^{\circ} \mathrm{C}$ during the months of February and June (mean annual maximum of $24.9^{\circ} \mathrm{C}$ and mean annual minimum of $17.1^{\circ} \mathrm{C}$ ), respectively (DCE, 2002, Figure 1a). The total annual precipitation was $1,371.8 \mathrm{~mm}$ (DAEE, 2002) $(1,278.0 \mathrm{~mm}$ mean $)$, and the accumulated precipitation for months between April and August corresponded to only $21 \%$ of the total precipitation, with the remainder distributed through the other months. Figure $1 \mathrm{~b}$ depicts the relation between temperature and precipitation $\left(R^{2}=0.84\right)$.

Forty one areas with different ground covers were visited monthly (Table 1). The measured LAI values in the study area ranged from a minimum of 0.16 and a maximum of 4.90, in sugarcane and riparian forest areas, respectively. The LAI measurements showed a mean standard deviation of 0.13 , and $80 \%$ of the standard deviation values were smaller than 0.20 . It must be taken into account that part of the variation in LAI measured between months, for different ground covers in each area, was attributed to the fact that measurement locations were not precisely the same; despite the fact that the selected areas were as homogeneous as possible, they still showed internal variations in vigor, and were not located precisely, since the GPS receptor utilized to locate the measurement points showed a positioning error of approximately $15 \mathrm{~m}$. An evaluation of LAI variation for different ground cover types found at the watershed is presented ahead.

The utilization of LAI-2000 to calculate LAI in forest areas can underestimate this index (Hingston et al., 1998; Battaglia et al., 1998), because of the violation of 
Table 1 - Results from LAI data collection in the field, where: FL, fallow; BS, bare soil; CS, cut sugarcane; SC, planted/ ratoon sugarcane; DP, dry pasture; CE, clear cut eucalyptus; and, NM, new maize.

\begin{tabular}{|c|c|c|c|c|c|c|c|c|c|c|c|c|c|c|c|}
\hline \multirow{2}{*}{ Area } & \multicolumn{2}{|c|}{ UTM Coordinates } & \multirow{2}{*}{ Use } & \multirow{2}{*}{ Jan } & \multirow{2}{*}{ Feb } & \multirow{2}{*}{ Mar } & \multirow{2}{*}{ Apr } & \multirow{2}{*}{ May } & \multirow{2}{*}{ Jun } & \multirow{2}{*}{ Jul } & \multirow{2}{*}{ Aug } & \multirow{2}{*}{ Sep } & \multirow{2}{*}{ Oct } & \multirow{2}{*}{ Nov } & \multirow{2}{*}{ Dec } \\
\hline & $\mathrm{E}(\mathrm{m})$ & $\mathrm{N}(\mathrm{m})$ & & & & & & & & & & & & & \\
\hline 1 & 220157 & 7473893 & Sugarcane & FL & FL & FL & FL & FL & 0.48 & 0.37 & 0.35 & 0.57 & 1.42 & 1.61 & 1.81 \\
\hline 2 & 220255 & 7476812 & Sugarcane & $\mathrm{BS}$ & $\mathrm{BS}$ & BS & BS & BS & BS & 0.31 & 0.65 & 1.41 & 2.22 & 2.60 & 2.82 \\
\hline 3 & 220233 & 7476759 & Sugarcane & 0.97 & 1.07 & 1.18 & 1.07 & 1.57 & 1.58 & 1.51 & $\mathrm{SC}$ & 0.33 & 0.21 & 0.60 & 0.79 \\
\hline 4 & 220389 & 7476709 & Sugarcane & 2.25 & 2.48 & 1.96 & 2.53 & 2.95 & 3.24 & CS & $\mathrm{SC}$ & 0.32 & 0.42 & 1.03 & 1.43 \\
\hline 5 & 220348 & 7476595 & Sugarcane & 0.47 & 0.7 & 1.05 & 1.03 & 2.56 & 2.18 & 2.15 & $\mathrm{SC}$ & 0.40 & 0.37 & 0.65 & 1.05 \\
\hline 6 & 220114 & 7476056 & Sugarcane & 1.01 & 0.96 & 0.68 & 0.60 & 1.09 & 1.33 & 1.42 & 1.67 & 1.67 & 1.30 & $\mathrm{SC}$ & 0.58 \\
\hline 7 & 220202 & 7476038 & Sugarcane & 1.24 & 2.35 & 2.09 & 1.68 & 1.39 & 1.53 & 1.66 & 1.90 & 2.17 & 0.68 & $\mathrm{SC}$ & 0.38 \\
\hline 8 & 220097 & 7475955 & Sugarcane & 1.58 & 1.53 & 1.09 & 0.74 & 1.98 & 1.30 & 1.68 & 1.59 & 1.56 & 2.01 & $\mathrm{SC}$ & 0.31 \\
\hline 9 & 220094 & 7475876 & Sugarcane & FL & FL & FL & FL & FL & FL & $\mathrm{SC}$ & 0.3 & 0.69 & 1.1 & 1.47 & 1.57 \\
\hline 10 & 220347 & 7475839 & Riparian forest & 3.21 & 3.26 & 2.89 & 2.48 & 2.34 & 2.43 & 2.56 & 1.96 & 1.71 & 2.66 & 2.93 & 3.12 \\
\hline 11 & 220361 & 7475832 & Riparian forest & 4.48 & 4.90 & 3.90 & 3.59 & 3.28 & 2.59 & 3.42 & 2.59 & 3.16 & 2.96 & 4.51 & 4.61 \\
\hline 12 & 220223 & 7475790 & Sugarcane & 2.05 & 1.94 & 1.76 & 2.02 & 2.26 & 2.43 & $\mathrm{CS}$ & 0.36 & 0.51 & 0.38 & 0.91 & $\mathrm{SC}$ \\
\hline 13 & 220127 & 7474952 & & 2.29 & 2.25 & 2.39 & 2.87 & 2.25 & 1.92 & ה & $\mathrm{SC}$ & $\mathrm{SC}$ & $\mathrm{C}$ & 0.79 & 0.92 \\
\hline 14 & 220133 & 7474858 & arcane & 1.93 & 2.17 & 1.72 & 1.27 & 1.44 & 2.09 & 2.85 & 2.53 & 1.9 & 3.00 & 0.74 & 1.11 \\
\hline 15 & 219942 & 7474156 & Sugarcane & 0.82 & 1.48 & 1.75 & 1.87 & 1.73 & 1.47 & 2.06 & 1.82 & 1.87 & 1.98 & $\mathrm{SC}$ & $\mathrm{SC}$ \\
\hline 16 & 219992 & 7473986 & Sugarcane & 0.86 & 0.72 & 0.72 & 0.74 & 0.87 & 0.93 & 1.15 & 1.28 & 1.52 & $\mathrm{SC}$ & 0.67 & 0.86 \\
\hline 17 & 219988 & 7473839 & & 1.01 & 1.54 & 1.36 & 1.07 & 1.41 & 1.53 & CS & BS & BS & BS & BS & BS \\
\hline 18 & 219 & 7473802 & & & & & & & & & & & & .55 & 1.85 \\
\hline 19 & 221075 & 7476404 & Sugarcane & FL & FL & FL & FL & FL & $\mathrm{SC}$ & 0.18 & 0.16 & 0.63 & 0.81 & 1.34 & 1.96 \\
\hline 20 & 221010 & 7476258 & Sugarcane & 1.82 & 2.07 & 1.67 & 2.10 & 2.53 & 2.65 & 2.28 & BS & $\mathrm{SC}$ & 0.51 & 0.48 & 1.32 \\
\hline 21 & 220948 & 7476160 & Sugarcane & 1.39 & 1.69 & 2.33 & 2.18 & 2.85 & 2.81 & 1.46 & 1.76 & 1.93 & 1.60 & $\mathrm{SC}$ & 0.59 \\
\hline 22 & 221300 & 7476780 & Sugarcane & 2.00 & 2.06 & 1.83 & 2.11 & 2.04 & 2.67 & $\mathrm{CS}$ & 0.28 & 0.86 & 0.55 & 0.86 & 0.70 \\
\hline 23 & 221510 & 7476721 & & & FL & FL & FL & FL & & & & & & 2.16 & 3.07 \\
\hline 24 & 221702 & 7476460 & Pasture & 2.11 & 1.79 & 2.00 & 1.61 & 1.73 & 1.25 & 1.44 & PS & 0.67 & 0.82 & 0.72 & 0.97 \\
\hline 25 & 222226 & 7476286 & Maize & 1.26 & FL & FL & FL & FL & FL & BS & BS & BS & NM & 1.61 & 2.42 \\
\hline 26 & 222221 & 7476249 & Pasture & 1.49 & 0.77 & 2.43 & 0.69 & 1.52 & 2.43 & 1.54 & PS & 1.14 & 0.96 & 0.72 & 0.66 \\
\hline 27 & 222996 & 7476016 & Sugarcane & 1.71 & 1.96 & 2.34 & 1.84 & 2.81 & 2.25 & $C$ & 0.26 & 0.67 & 0.69 & 0.75 & 1.47 \\
\hline 28 & 222691 & 7475382 & Sugarcane & 0.64 & 0.81 & 0.69 & & & 0.81 & $\mathrm{SC}$ & 0.18 & 0.77 & 0.74 & 0.72 & 1.47 \\
\hline 29 & 222647 & 7475289 & Sugarcane & 1.18 & 1.22 & 0.96 & 1.27 & 1.33 & $\mathrm{CS}$ & 0.29 & 0.58 & 1.02 & 0.78 & 0.85 & 1.19 \\
\hline 30 & 223682 & 7474525 & Sugarcane & 0.86 & 1.15 & 2.33 & 2.18 & 2.04 & 2.43 & 3.04 & 2.38 & 2.89 & 2.59 & $\mathrm{SC}$ & 0.51 \\
\hline 31 & 222358 & 7473364 & Sugarcane & 1.34 & 1.68 & 2.36 & 2.17 & 2.94 & 2.45 & CS & 0.37 & 0.39 & 0.54 & 1.45 & 1.60 \\
\hline 32 & 222403 & 7473290 & Eucalyptus & 2.78 & 2.86 & 3.13 & 3.00 & 2.74 & 2.40 & 2.15 & 2.52 & 2.24 & 2.27 & 2.45 & 2.51 \\
\hline 33 & 222084 & 7473237 & Sugarcane & $\mathrm{SC}$ & 0.76 & 0.58 & 1.07 & 1.25 & 1.57 & 1.57 & 2.05 & 1.69 & 1.33 & 2.00 & $\mathrm{SC}$ \\
\hline 34 & 222106 & 7473163 & Sugarcane & BS & BS & BS & BS & BS & $\mathrm{SC}$ & 0.12 & 0.36 & 0.53 & 1.01 & 2.16 & 2.52 \\
\hline 35 & 222192 & 7473000 & Sugarcane & 0.47 & 1.02 & 1.32 & 0.71 & 1.36 & 1.48 & 1.88 & 1.88 & 1.58 & $\mathrm{SC}$ & 0.50 & 0.65 \\
\hline 36 & 221950 & 7473187 & Pasture & 2.03 & 2.04 & 2.06 & 1.45 & 1.70 & 1.79 & 1.3 & 0.85 & 1.18 & 0.86 & 0.66 & 1.81 \\
\hline 37 & 220850 & 7474194 & Pasture & 1.09 & 1.65 & 2.45 & 2.18 & 2.28 & 1.96 & 1.78 & PS & 1.37 & 1.49 & 1.64 & 1.83 \\
\hline 38 & 220892 & 7474086 & Sugarcane & 2.22 & 2.01 & 1.65 & 2.58 & 2.53 & 2.88 & 3.34 & 2.13 & $\mathrm{SC}$ & $\mathrm{SC}$ & 0.75 & 1.12 \\
\hline 39 & 221882 & 7473915 & Sugarcane & BS & BS & BS & BS & BS & $\mathrm{SC}$ & 0.34 & 0.54 & 0.81 & 1.18 & 1.62 & 2.33 \\
\hline 40 & 221978 & 7473685 & Eucalyptus & 1.99 & 2.30 & 2.07 & 2.05 & 1.95 & 2.20 & 2.19 & 2.00 & 1.74 & 1.84 & 1.66 & $\mathrm{CE}$ \\
\hline 41 & 222600 & 7474360 & Eucalyptus & 3.11 & 3.11 & 2.44 & 2.34 & 2.39 & 2.45 & 1.83 & 2.12 & 2.41 & 2.50 & 2.48 & $\mathrm{CE}$ \\
\hline
\end{tabular}

some assumptions required by the methodology to calculate LAI with this equipment, which may not occur under forest canopies, for instance the random distribution of leaves, since leaf overlapping usually occurs in forest canopies (Chen et al., 1991).

The most typical species that occur in the region's riparian forest areas are: fig trees (Ficus spp.), louveira (Cyclolobium vecchii A. Samp.), guanandi (Callophyllum brasiliensis Camb.), inga trees (Inga affinis CD. Hook et
Arn), and canela-do-brejo (Endlicheria paniculata (Spreng.) Macbr.), among others (Rodrigues, 1999). Two riparian forest areas were observed throughout the year, and the mean LAI was 3.14, with a maximum of 4.90 (February, area 11), recorded after the rainy months (Figure 2a). The smallest LAI value was 1.71 (area 10), recorded during the last dry month (September). No LAI value for this type of ground cover was found in the literature for comparison purposes. 


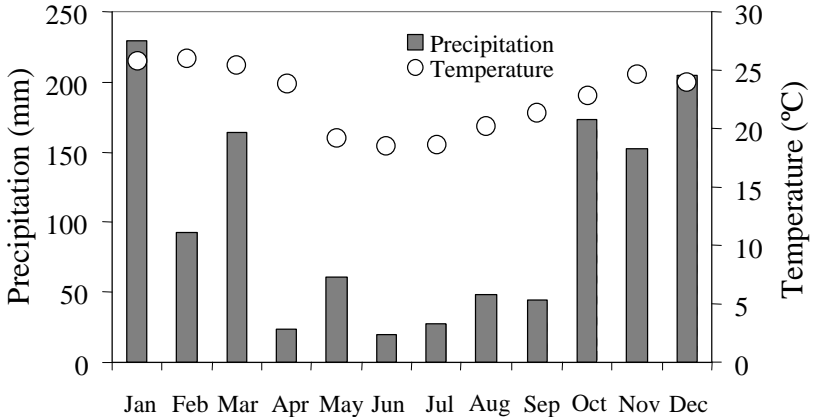

(a)

Month

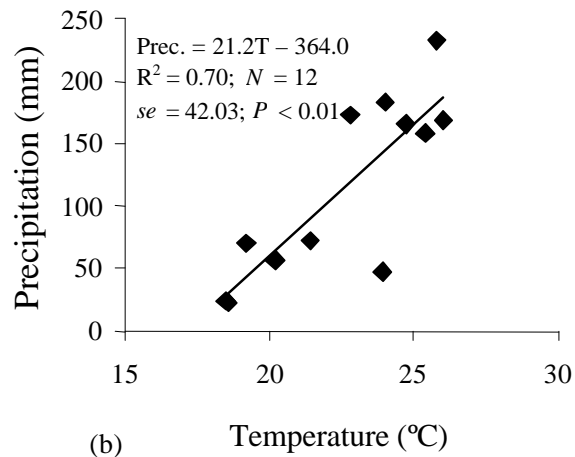

(b) Temperature $\left({ }^{\circ} \mathrm{C}\right)$

Figure 1 - Climatological data for the Ribeirão dos Marins watershed. Precipitation variation (DAEE, 2002) and mean monthly temperature (a) and its corresponding scatter diagram (b), where: $\mathrm{R}^{2}$ is the coefficient of determination; $N$ is the number of samples; $s e$ is the standard error of the estimate and $P$ is the level of significance.

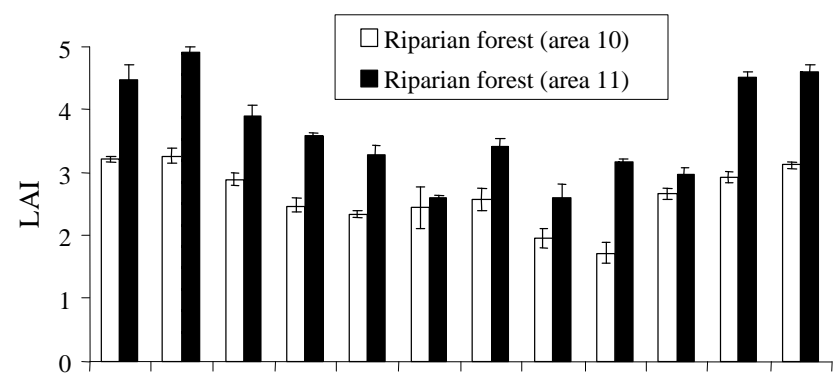

Jan Feb Mar Apr May Jun Jul Aug Sep Oct Nov Dec

(a)

Month

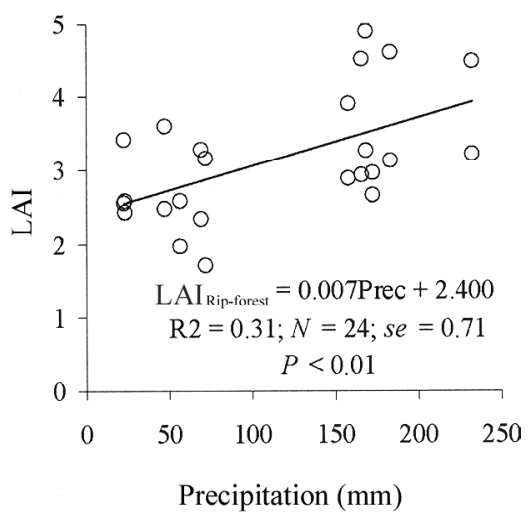

Figure 2 - LAI variation throughout the year with the corresponding confidence interval (95\% confidence) (a) and monthly LAI scatter diagram for the riparian forest with the corresponding precipitation (b).

The reason for LAI variation in the riparian forest is related to traits of this type of vegetation, which is semideciduous, i.e., part of the species shed their leaves under water stress. As a matter of fact, LAI shows a dependence relationship with precipitation (Figure $2 b$ ), with a positive correlation of 0.57 .

Figure 3 shows the variation in LAI for adult eucalyptus throughout the year, in the three areas where measurements were obtained for this variable. Minimum, maximum and mean LAI values in those areas were 1.66 (area 40, November), 3.13 (area 32, March) and 2.36, respectively. In December, two areas planted with eucalyptus were clear cut (areas 40 and 41). The LAI-2000 equipment has been utilized by several authors to estimate LAI in eucalyptus (Hingston et al., 1998; Xavier et al., 2002; Ares \& Fownes, 2000). In addition to the edaphic and climatic factors that cause LAI variations, Xavier et al. (2002) observed that LAI was distinct for different genetic materials with the same age and that LAI can either become stabilized or show decline with age.

Ares \& Fownes (2000) observed that LAI in eucalyptus plantations decreased as the local altitude increased, but this does not explain LAI variations in our study area, located practically at the same altitude,

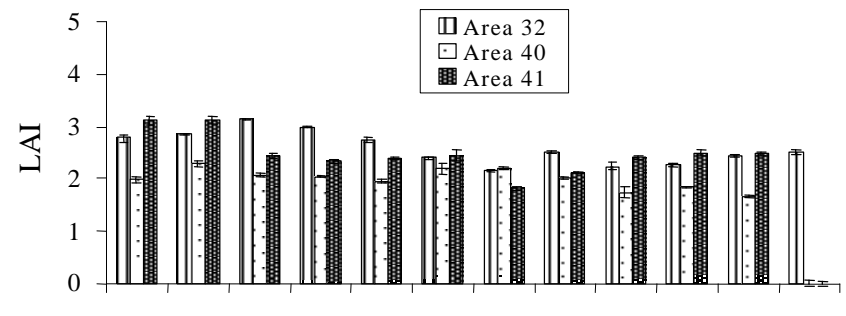

Jan Feb Mar Apr May Jun Jul Aug Sep Oct Nov Dec

Month

Figure 3 - LAI variation throughout the year for eucalyptus plantations with corresponding confidence interval.

approximately $600 \mathrm{~m}$. Xavier et al. (2002) in Brazil, and Hingston et al. (1998), in Australia, found a maximum LAI of 4.31 and 4.03, respectively, measured with the LAI-2000 device. LAI variability in this crop is quite high, depending on factors such as those mentioned before, so that the LAI data found in this work are in agreement with those found in other studies.

No relationship between LAI and monthly precipitation or mean monthly temperature was observed. For the most part of the year, LAI values for eucalyptus in the three areas were distinct $(P<0.05)$. In area 41 there was a $25 \%$ LAI decrease along the months, while in the 
other areas (32 and 40) this was not verified, since the mean values for January and December were equal $(P<0.05)$.

The estimation of LAI values with the LAI-2000 equipment in pasture areas is subject to restrictions because of the sensor's height (Welles \& Norman, 1991), which is $3 \mathrm{~cm}$. Therefore, the index can be underestimated in shallow pastures. However, the studied pastures showed heights always above $10 \mathrm{~cm}$, except in August, when no measurements were made since they were completely dry, because of drought and/or heavy grazing. The highest, lowest, and mean LAI values measured in pasture areas were 2.45 (area 26, June), 0.66 (area 36, November) and 1.49 , respectively (Figure 4$)$. LAI values determined by the weighings method (Daughtry, 1990) in Brazil varied from 0.49 to 3.90 (Roberts et al., 1996). Because of the crop's intense dynamics, related to cattle grazing, no significant LAI relationship was found, either with the monthly precipitation or with the mean temperature.

The highest LAI value in sugarcane was 3.34 (area 38, July), which is lower than values found in other studies (Keating et al., 1999; Cheeroo-Nayamuth et al., 2000), and even lower than the measurement made by Machado et al. (1982), in the same region (3.70, 300-day old sugarcane). In addition to the relative measurements provided by the LAI-2000 equipment, the highest LAI values must be associated with the fact that the type of genetic material is distinct, and the management techniques utilized for the crop are different (for example: spacing between plants, fertilization, irrigation etc.) in the several study areas.

In the area under study, sugarcane planting/regrowth is concentrated in the beginning of the first semester, with harvest occurring after 18 months (1.5-year old sugarcane) or in the middle of the second semester if harvest happens after 12 months (one-year old sugarcane) (Koffler et al., 1979). Figure 5 represents the temporal variability for planting/regrowth and for LAI development in sugarcane planted or cut in the months of June and July (Figure 5a), extending through October and November (Figure 5c), coincident with the beginning of the rainy

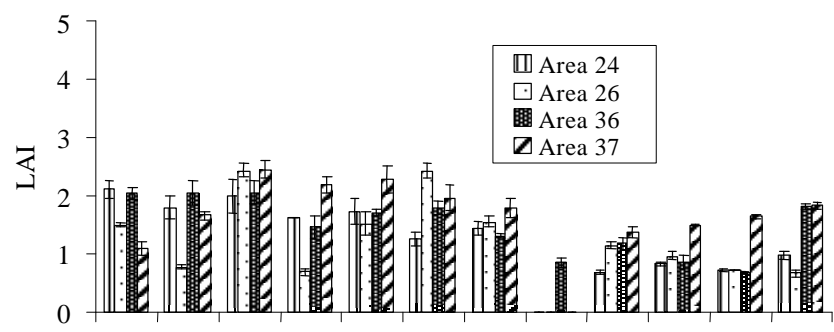

Jan Feb Mar Apr May Jun Jul Aug Sep Oct Nov Dec

Month

Figure 4 - LAI variation throughout the year for pasture with its corresponding confidence interval $(P<0.05)$.
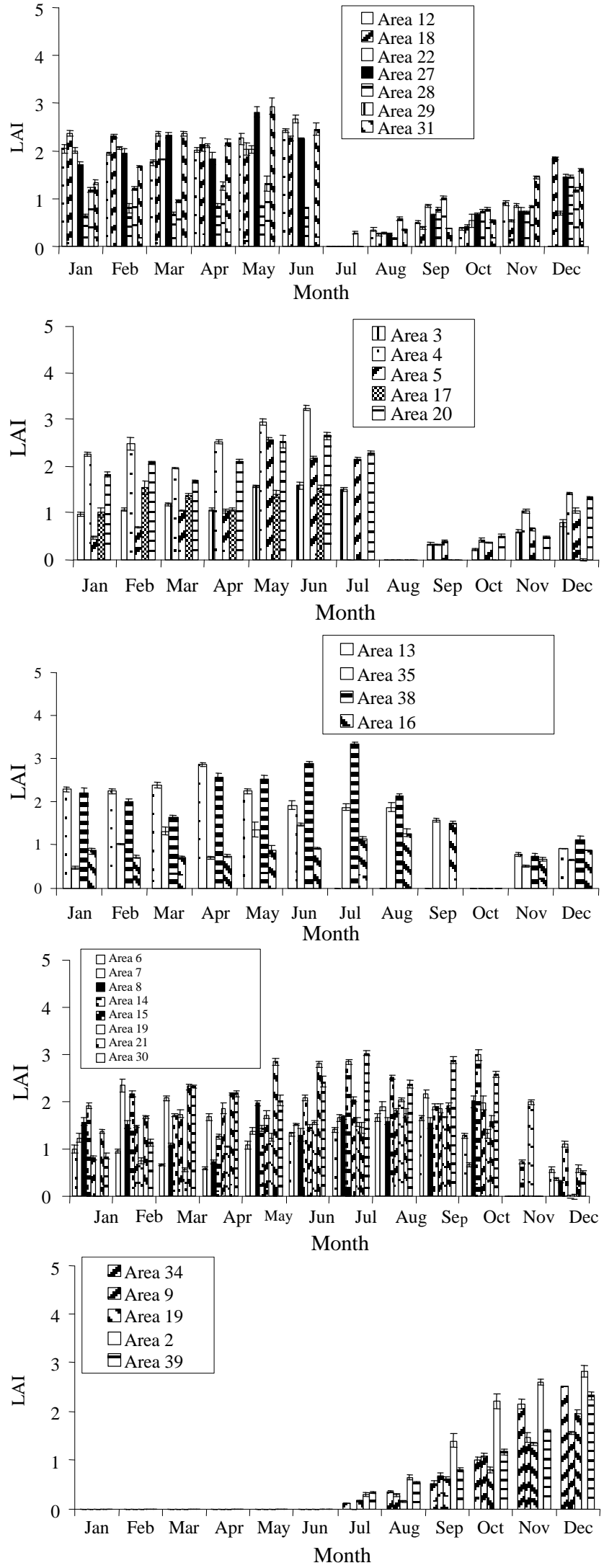

Figure 5 - LAI dynamics for the sugarcane crop according to planting months: June and July (a); August and September (b); October and November (c); without a defined planting month (d); and, fallowing area until May but planted in June and July (e). 
season in the region. Some areas under observation were fallowed until June, when planting was done (Figure 5e). Finally, Figure $5 \mathrm{~d}$ presents the areas where planting season could not be determined.

Figure 6 presents the relationship of sugarcane LAI with planting/regrowth month (Planting) and the crop's age (Age), for field-collected samples, where only LAI data from Figures 5a, 5b, 5c and 5e were considered, hence these areas were planted with sugarcane grown at a 12-month cycle. Samples in Figure 5d were not considered, since the planting season could not be established. The total LAI variation explained by the planting month and crop age was 47\% $(P<0.01)$. LAI showed the highest values after approximately 10 months after planting, in agreement with results of Machado et al. (1982). It is quite difficult to generate LAI maps during a given season in a watershed without a good knowledge of land use, since each sugarcane area has its own planting season and age and, therefore, distinct LAI developments. The mean error while obtaining LAI estimates was 0.65 . LAI $=f($ Age, Planting $)$ was determined by:

$\mathrm{LAI}=-0.7647+0.6219$ Age $^{-0.0227 \text { Age }^{2}+0.0085 \text { Planting }^{2}}$ -0.0221Age.Planting,

Two maize stands planted in October were observed; the maximum LAI value obtained was 3.07 (area 23). A reference point is provided by Oliveira et al. (1993), who obtained a maximum LAI of 2.45 with irrigated maize in Brazil. Again, differences in genetic material and management between the studies explain this difference.

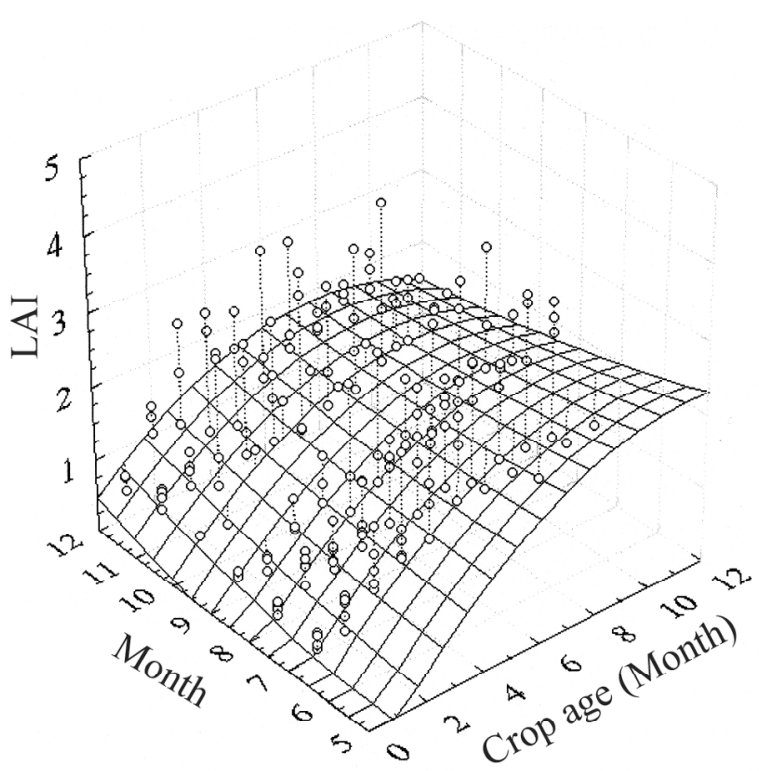

Figure 6 - Sugarcane LAI relationship with planting season and crop age.

\section{CONCLUSIONS}

LAI data found in this work are not conclusive, since the LAI measurements obtained with the LAI-2000 equipment are relative. An evaluation between the LAI estimate obtained with LAI-2000 and the LAI evaluated by direct measurements should be done in future studies. The measured LAI data showed great temporal variability, depending on the type of cover, climatological conditions and type of management.

\section{ACKNOWLEDGEMENTS}

To Fundação de Amparo a Pesquisa do Estado de São Paulo Research Foundation (FAPESP) for the financial support to this study (2000/09325-0) and for the fellowship for the first author (98/14499-5).

\section{REFERENCES}

ARES, A.; FOWNES, J.H. Productivity, nutrient and water-use efficiency of Eucalyptus saligna and Toona ciliata in Hawaii. Forest Ecology and Management, v.139, p.227-236, 2000.

BATTAGLIA, M.; CHERRY, M.L.; BEADLE, C.L.; SANDS, P.J.; HINGSTON A. Prediction of leaf area index in eucalypt plantations: effects of water stress and temperature. Tree Physiology, v.18, p.521$528,1998$.

BETTS, R.A.; COX, P.M.; LEE, S.E.; lan WOODWARD, F. Contrasting physiological and structural vegetation feedbacks in climate change simulations. Nature, v.387, p.796-799, 1997.

CHEEROO-NAYAMUTH, F.C.; ROBERTSON, M.J.; WEGENER, M.K.; NAYAMUTH, A.RH. Using a simulation model to assess potential and attainable sugar cane yield in Mauritius. Field Crops Research, v.66, p.225-243, 2000.

CHEN, J.M.; BLACK, T.A.; ADAMS, R.S. Evaluation of hemispherical photography for determining plant area index and geometry of a forest stand. Agricultural and Forest Meteorology, v.56, p.129-143, 1991.

DAUGHTRY, C.S.T. Direct measurement of canopy structure. In: GOEL, N.S.; NORMAN, J.M. (Ed.) Instrumentation for studying vegetation canopies for remote sensing in optical and thermal infrared regions. New York: Harwood Academic, 1990. p.45-60.

DEPARTAMENTO DE ÁGUAS E ENERGIA ELÉTRICA. http:// www.daee.sp.gov.br/servicos/tabbmt.htm. (10 jan. 2002).

DEPARTAMENTO DE CIÊNCIAS EXATAS. http://www.ciagri.usp.br/ emdabreu/MEDIAS.TXT. (10 jan. 2002).

DEERING, D.W.; ECK, T.F.; BANERJEE, B. Characterization of the reflectance anisotropy of boreal forest canopy in spring-summer. Remote Sensing of Environment, v.67, p.205-229, 1999.

GOETZ, S.J. Multi-sensor analysis of NDVI, surface temperature and biophysical variables at a mixed grassland site. International Journal of Remote Sensing, v.18, p.71-94, 1997.

HINGSTON, F.J.; GALBRAITH, J.H.; DIMMOCK, G. M. Application of the process-based model BIOMASS to Eucalyptus globulus subsp. globulus plantations on ex-farmland in southwestern Australia - I. Water use by trees and assessing risk of losses due to drought. Forest Ecology and Management, v.106, p.141-156, 1998.

KEATING, B.A.; ROBERTSON, M.J.; MUCHOW, R.C.; HUTH, N.I. Modelling sugarcane systems: I. Development and performance of the sugarcane module. Field Crops Research, v.61, p.253-271, 1999.

KOFFLER, N.F.; CAVALLI, A.C.; CHIARINI, J.V.; NOGUEIRA, F.P. Inventário canavieiro com o auxílio de fotografias aéreas. Boletim Técnico Planalsucar, v.1, p.3-38, 1979.

LI-COR. LAI-2000 plant canopy analyzer: instruction manual. Nebraska, 1992. 182p. 
MACHADO, E.C.; PEREIRA, A.R.; FAHL, J.I.; ARRUDA, H.V.; CIONE J. Índices biométricos de duas variedades de cana-de-açúcar. Pesquisa Agropecuária Brasileira, v.17, p.1323-1329, 1982.

MATSUSHITA, B.; TAMURA, M. Integrating remotely sensed data with an ecosystem model to estimate net primary productivity in East Asia. Remote Sensing of Environment, v.81, p.58-66, 2002.

MYNENI, R.B.; MAGGION, S.; IAQUINTA, J.; PRIVETTE, J.L.; GOBRON, N.; PINTY, B.; KIMES, D.S.; VERSTRAETE, M.M.; WILLAMS, D.L. Optical remote sensing of vegetation: modeling, caveats, and algorithms. Remote Sensing of Environment, v.51, p.169-188, 1995.

OLIVEIRA, F.A.; SILVA, J.J.S.; CAMPOS T.G.S. Evapotranspiração e desenvolvimento radicular do milho irrigado. Pesquisa Agropecuária Brasileira, v.28, p.1407-1415, 1993.

OLIVEIRA, J.B. Solos da folha de Piracicaba. Campinas: Instituto Agronômico, 1999. 173p. (Boletim Científico, 48).

ROBERTS, J.M.; CABRAL, O.M.R.; da COSTA, J.P.; McWILLIAN, A.L.C.; de A. SÁ, T.D. An overview of the leaf area index and physiological measurements during ABRACOS. In: GASH, J.H.C.; NOBRE, C.A.; ROBERTS, J.M.; VICTORIA, R.L. (Ed.) Amazon deforestation and climate. Chichester: John Wiley, 1996. p.287-306.

RODRIGUES, R.R. A vegetação de Piracicaba e municípios do entorno. Piracicaba: IPEF, 1999. 18p. (Circular Técnica, 189).

SAIGUSA, N.; OIKAWA, T.; LIU, S. Seasonal variations of the exchange $\mathrm{CO}_{2}$ and $\mathrm{H}_{2} \mathrm{O}$ between a grassland and the atmosphere: An experimental study. Agricultural and Forest Meteorology, v.89, p.131-139, 1998.

SELLERS, P.J.; DICKINSON R.E.; RANDALL, D.A.; BETTS, A.K.; HALL, F.G.; BERRY, J.A.; COLLATZ, G.J.; DENNING, A.S.; MOONEY, H.A.; NOBRE, C.A.; SATO, N.; FIELD, C.B.; HENDERSON-SELLERS, A. Modeling the exchanges of energy, water, and carbon between continents and the atmosphere. Science, v.275, p.502-509, 1997.

SENTELHAS, P.C.; MARIN, F.R.; PEREIRA, A.R.; ANGELOCCI, L.R.; VILLA NOVA, N.A.; BARBIERI, V. Analise dos dados climáticos e do balanço hídrico climatológico de Piracicaba. Piracicaba: ESALQ, Depto. de Física e Meteorología. 1998. 81p.
TERAMOTO, E.R. Relações solo, substrato geológico e superfícies geomórficas na microbacia do Ribeirão dos Marins (Piracicaba, SP). Piracicaba: USP/ESALQ, 1995. 93p. (Dissertação - Mestrado)

TURNER, D.P.; COHEN, W.B.; KENNEDY, R.E.; FASSNACHT, K.S.; BRIGGS, J.M. Relationships between leaf area index and Landsat TM Spectral Vegetation Indices across three temperate zone sites. Remote Sensing of Environment, v.70, p.52-68, 1999.

VAN DIJK, A.I.J.M.; BRUIJNZEEL, L.A. Modelling rainfall interception by vegetation of variable density using an adapted analytical model Part 2. Model validation for a tropical upland mixed cropping system. Journal of Hydrology, v.247, p.239-262, 2001.

WATSON, D.J. Comparative physiological studies on growth of field crops: I. Variation in net assimilation rate and leaf area between species and varieties, and within and between years. Annals of Botany, v.11, p.4176, 1947.

WELLES, J.M. Some indirect methods of estimating canopy structure. In: GOEL, N.S.; NORMAN, J.M. Instrumentation for studying vegetation canopies for remote sensing in optical and thermal infrared regions. London: Harwood Academ Publishers, 1990. cap.5, p.31-43.

WELLES, J.M.; NORMAN, J.M. Instrument for indirect measurement of canopy architecture. Agronomy Journal, v.83, p.818-825, 1991.

WIEGAND, C.L.; RICHARDSON, A.J. Use of spectral vegetation indices to infer leaf area, evapotranspiration and yield: II. Results. Agronomy Journal, v.82, p.630-636, 1990.

XAVIER, A.C.; SOARES, J.V.; ALMEIDA, A.C. Variação do índice de área foliar em clones de eucalipto ao longo de seu desenvolvimento. Revista Árvore, v.26, p.421-427, 2002.

Received August 30, 2002

Accepted April 28, 2003 